\title{
Anthropological publics, public anthropology
}

Edited, referenced, and footnoted by Sindre

BANGSTAD, KIFO (Institute for Church, Religion

and Worldview Research)

Sindre BANGSTAD, KIFO (Institute for Church, Religion and Worldview Research); Irfan AHMAD, Australian Catholic University; John R. Bowen, Washington University St. Louis; Ilana FELDMAN, George Washington University; Angelique Haugerud, Rutgers University; David H. PRICE, St. Martin's University; Richard Ashby Wilson, University of Connecticut; Mayanthi L. Fernando, University of California, Santa Cruz

Based on a transcript from the AAA 2016 roundtable on "anthropological publics, public anthropology," organized by Sindre Bangstad, held at the AAA Annual Meeting in Minneapolis, Minnesota, on November 18, 2016, and edited, referenced, and footnoted by Sindre Bangstad, this forum explores prominent anthropologists' experiences of doing "public anthropology," and asks what kind of structural impediments there are in our time to the engagement of wider publics for a "public anthropology," and what anthropologists can do better.

Keywords: public anthropology, the public sphere, engaged anthropology, applied anthropology, neoliberalism.

This work is licensed under the Creative Commons | ( ) Sindre Bangstad, Irfan Ahmad, John R. Bowen, Ilana Feldman, Angelique Haugerud, David H. Price, Richard Ashby Wilson, Mayanthi L. Fernando. 
SINDRE BANGSTAD: Last week most, if not all, of us realized that we had woken up to a political nightmare which challenges the very normative foundations of anthropological thought and practice. ${ }^{1}$ As a Norwegian, however, I could not help but think, "Welcome to my world." And I am not saying here that Norway is fundamentally similar to the United States. But unknown to many of you, I suppose, Norway has since October 2013 had its most right-wing government since World War II. This is a government which includes the populist right-wing Progress Party, a party whose main mobilizational and electoral platform is anchored in opposition to immigration in general and Muslim immigration in particular. For many of us, this turn in Norwegian politics represented a bit of a paradox, in that we had hoped that the debate which followed in the wake of the worst terrorist attacks in Norwegian history, perpetrated by a white right-wing extremist and one-time Progress Party member, Anders Behring Breivik, on July 22, 2011 might have enabled a greater inspection of the state of public discourse about Islam and Muslims in Norway. That, however, has in all respects been proven to be a false assumption. I myself wrote the monograph Anders Breivik and the rise of Islamophobia about the background of these terrorist attacks (Bangstad 2014). Though it was reviewed in the New York Review of Books, the London Review of Books, and American Ethnologist, it was completely ignored by Norwegian mainstream media. A great deal of research funding available for anthropology in Norway comes from the state. This also means that many of my fellow Norwegian anthropologists, for perfectly understandable reasons, have reacted with studied silence in the face of the new political and intellectual climate that has been ushered in.

This is a climate in which anthropology has in far-right and populist right-wing circles come to embody, at best, an irrelevant interest in and respect for human difference, and, at worst, a pernicious threat against the rising from the historical ashes of the far-right in contemporary Europe. We live in Dark Times on both sides of the Atlantic and many other places, and anthropologists who think that society and our shared humanity need to be defended against these encroaching Dark Times certainly have their work cut out for them. My initiative to this roundtable arose from a series in public anthropology that I initiated in 2009. The background to that series was that when I first started out doing anthropology as an undergraduate in the mid-1990s, the discipline commanded much more public attention and interest than it currently does in Norway. Now, a lot of US anthropologists tend to think of Norway and Scandinavia in general as places in which anthropology has a strong public presence, in contradistinction with the United States, and of Norway as a country in which anthropologists are listened to in the public sphere. I fear I have to say that this no longer really applies. So I realized quite quickly after I had moved back to Norway in 2007 after completing my Ph.D. dissertation on Muslims in Cape Town, South Africa, that there was a need to make the argument for the relevance of anthropological thought and practice anew. And so I started a series at the recently opened House of Literature in Oslo with funding from the private Fritt Ord Foundation, and decided that in this series I would invite prominent

1. This roundtable took place a week after the US presidential elections of November 9, 2016, in which the Republican Party's candidate, Donald Trump, was elected as US president after Barack Obama. 
international anthropologists and put them in front of a nonspecialist audience to talk about their work. This series ran from 2009 to 2014, and forms the basis of a forthcoming edited volume, Anthropology of our times (Bangstad forthcoming).

I also learned in the course of this series much about the strictures in our times which mitigate against a wider reach and impact of anthropological thought and practice. These include, of course, a political economy in contemporary academia in which doing public anthropology is generally not rewarded, and may in fact constitute an obstacle to both tenure and promotion, in the sense that in a neoliberal world people who tend to be too critical and too outspoken may often find themselves constituting too much of "a problem" in the academic context. There is of course also the increasing fragmentation and polarization in and between various publics and counterpublics facilitated by the social media and its attendant information overload in the attention economy, and a dwindling legitimacy and reach for mainstream media, which applies in Norway almost as much as it does in the United States. And there is also the rise of a far-right nationalism which is anathema to anything and everything anthropology and anthropologists have ever been supposed to represent.

So, let me finally say something briefly about the format for this roundtable. I have asked our panelists to address a set of five questions:

1. What kind of positive or negative experiences have you yourself had in doing public anthropology?

2. Is the term public anthropology a term you yourself would use for what you are doing, and if not, why not? How would you yourself define the term or its alternatives? Some, like Didier Fassin (2013), prefer to talk about 'public ethnography' instead.

3. To whom are your public interventions addressed?

4. How do we make the case for public anthropology and by which means and strategies?

5. What could anthropologists do better in public? We often seem to blame people other than ourselves, and particularly the media, when we assert that "no one wants to listen to anthropologists, and that is not our problem, and it is not our fault, it is everyone else's." And what kind of stated and unstated strictures are there within anthropology itself at particular times and in particular places?

IRFAN AHMAD: I begin with two propositions. First, if there is to be any meaning to the anthropological dictum that to know only one society is to know no society, we also have to add that to know only anthropology is to know no discipline. And by this, I do not mean the lazy ritual of only adding the prefix "anthropology of" before any particular phenomenon or body of knowledge. At the intersection of political science, international relations, religion, and philosophy, my public anthropology is mostly through the media. Applied anthropology is one aspect of public anthropology, but it is not always ethical. So my second proposition is that for anthropology to be public, it must also be ethical. I will present a case study of my own engagement, and conclude with two sets of questions which in my experience doing public anthropology raises. A week after the July 2011 bomb explosion 
in Mumbai, the journal Foreign Affairs invited me to write about terrorism in India. After the approval of the title and the abstract, I also sent the article to them. They edited it, and asked for a few clarifications. I clarified within two days. However, I heard no reply. I then sent off many reminders, after which, ten days later, I received the following email. And I quote:

Thanks again for your thorough work on the edits. I have shared the piece with editors at Foreign Affairs ... and our thoughts are ... that the piece does not offer ... a clear and systematic explanation of "homegrown" terrorism in India or homegrown Indian terror groups. ... The piece reads more like something for a specialist. ... To work for us, it would need ... rethinking and redrafting on your part.... We can pay you USD 150.

The amount of remuneration mentioned in this email was half of what was promised in the first email. My reply to Foreign Affairs was as follows: "Many thanks for your response. . . . I understand the editors' decision. However, the reasons listed are not convincing. Perhaps it is an issue of frameworks? Please do not send any money, I do not write for it."

Since I had spent a lot of time writing up this article, I sent it off to Al-Jazeera English instead (Ahmad 2011). Only an hour after it was published by them, Al-Jazeera sent me a rather alarming email with the subject heading "Need clarification ASAP." The email informed me that "your article is causing quite a stir." The reason for the stir was a threatening email sent to Al-Jazeera from one Praveen Swami, a journalist and "security expert" I had mentioned in my article. Swami's email was as follows:

Al-Jazeera has published an article by Dr. Irfan Ahmad . . . making a number of defamatory and inaccurate assertions about me and about my work. ... Dr. Ahmad suggests that Indian commentators ... on the Indian Mujahedin $(\mathrm{IM})^{2} \ldots$ are in error because during his fieldwork, Dr. Ahmad did not hear anything about the Indian Mujahedin. . . . Leaving aside his presumption that terrorists would discuss their plans with a visiting anthropologist, I note here that my articles on the IM network have stated that the IM was formed in 2005, after Dr. Ahmad's fieldwork had been completed. ${ }^{3}$ I hereby call upon al-Jazeera to remove Dr. Ahmad's article from its website, with an unconditional apology. Failing this, I shall initiate civil and criminal proceedings against Al-Jazeera.

What Swami wrote about my article does not reflect what I had actually written. My paragraph about Swami read as follows:

The media invariably base their stories on the sources of the state. An apt example is Praveen Swami, a terrorism expert cited by everyone writing about the IM.... Swami reproduces the police version [and I had

2. The knowledge about IM as a terrorist group is, according to Ahmad (personal correspondence, February 2017), exclusively derived from nontransparent Indian intelligence sources. Many, including prominent politicians, have therefore questioned whether the IM actually exists.

3. Swami here appears to refer to the doctoral fieldwork which went into Ahmad's 2009 monograph on the Jama'at-e-Islami in India (Ahmad 2009). 
references to three of his articles] ... without giving the other side of the story, namely the alleged terrorists, their family members, or the Muslim communities. Praveen Swami freely wrote about the Muslim terrorists he believes caused the terrorist blast. ..... However, the investigations later showed that Hindu nationalists carried out the Malegaon and Mecca mosque terror attacks."

In the next two hours I sent ample evidence to Al-Jazeera, stating that I stood by what I wrote. Al-Jazeera had to call a meeting with their team of legal experts, who concluded that Swami had no case. Al-Jazeera also offered him a right of response that Swami did not accept.

Other reactions to my article were no less interesting. Enter the world of Twitter! Ambarish Mohanty tweeted to declare that my article was "anti-India." Another tweeter, Nikhil Narayanan, declared that the author of the article "had just landed from another planet. He wants to know why SIMI [the Student Islamic Movement of India] was banned" by the Indian government two weeks after 9/11. A third, Nilim Dutta, tweeted to describe my article as "splendid crap by a political anthropologist." Let me mention here that I had quoted two anthropologists in my article, one being Thomas Hylland Eriksen and the other Peter van der Veer. Tweets and comments on the Al-Jazeera website not only characterized the article as "antiIndia"; I was also referred to as a "cryptosupporter of terrorism."

Anthropologists have historically been called all sorts of names. But "antinational" and "anti-India" is probably something unique to the case of India. The questions I raise, therefore, are these: How do anthropologists deal with nationalism of this kind? How do we intervene in public debates with this accusation of being "antinational" leveled against us? Are the nation and the public the same? In regard to my second question, note that my intervention in Al-Jazeera was never taken as an example of freedom of speech. By contrast, the diatribe of Subramanian Swamy, a prominent Indian politician and former minister with a doctorate from Harvard University, whom I had critiqued in the article for his open call to deprive Muslims of voting rights if they did not support a Hindu state, was justified in the name of freedom of speech. So the second question I pose is this: Does freedom of speech in other cases and for others mean freedom from speech?

JOHN BOWEN: We are all concerned right now. At Washington University, where I teach, we had an emergency meeting on Wednesday about how we deal with international students who are coming to our university to study. What can we say to these students? Very little, since we do not know anything yet. But what can we assure the students of? Well, we can assure them of our protection and their legal rights. But it is a moment when we really have to think through how we interact with the rest of the world, and with Muslims coming from the rest of the world in particular. But then we also have to think about how we talk to our fellow citizens about the problems we face, and how we deal with the future.

I personally do not have any grand announcements to make or solutions to propose. But I would like to mention three kinds of public interventions that I have recently made and that I make periodically. These are interventions which imply 
very different publics. The first relates to the day after the shootings at Charlie Hebdo and the kosher store in Paris, France (on January 7, 2015). I got a call from Time Magazine asking me whether I could do four hundred words in four hours. So I wrote a piece to that length and in that time-space (Bowen 2015), basically saying, "Here are three reasons why France is such a privileged target for people committing mass violence in Europe." "Why are there so many attacks in France?" And of course it got more complicated later, when the whole Belgian-Paris route opened up. But in the article I talked about the colonial history and the military presence of France. This was Time Magazine Online, and it turns out this gets circulated widely, and gets picked up in the Delhi Times, and lots of other places. So this was a mass public, and I had no idea who I was talking to. I had talked to some staffer at Time Magazine, but whatever happened after that was out of my control. In other words, a mass publication, a short communication, people reading, and it gets circulated because it is short. It can fit on one side of a sheet of paper, and it has got a very succinct message. So that is one example, and I will come back to the question as to in what ways these are anthropological publics. I am less sure about that than about these having been diverse publics.

My second example is very different, and relates to work I have done for several years with a policy group attached to the Ministry of Justice in Britain, including lawyers, Muslim intellectuals, activists within Muslim communities and so on. We have debated several policy issues over the years. Here, the public is public in the sense of public policy, and the involvement of the state in changing things. We had a particular recommendation we wanted to make. It is fairly complicated. But basically in England and Wales, it is buildings that are allowed to perform marriages. So, if an imam wants to go to a house and perform a marriage, it will not have a legal effect. In order to have a legal effect, it has to take place in a building that is registered as having the competence of having a marriage performed there. The Anglican churches are all in, the Catholic churches are all in, but other houses of worship have to apply one by one. What this means is that, owing to the fact that most Muslim marriages are not conducted in mosques-and most mosques are not even registered-most Muslim marriages are conducted at home. It is therefore very difficult for most Muslims to have their marriages registered. This means that they get married religiously, and it is not registered by the state. They buy a house and the house is in the husband's name; if the husband walks out on the marriage, the wife has no recourse if there are no children. So it would be good to make it as easy as possible for couples to register their marriage with the state. And that was a case where I could contribute a lot since I had spent a great deal of time researching this for my book on British Islam (Bowen 2016).

Much of that time was spent working on issues relating to sharia councils, which are religious bodies that may give Muslim women divorces. And so I knew quite a bit about these bodies, and about the problems Muslim women had when their marriages did not go so well. And so I could back that up with a number of recommendations about what is called "celebrant status," which applies in Scotland, and where a priest can go practically anywhere and perform a marriage, and to try to adopt that in England and Wales in order to facilitate marriage. So in this case, it is a very different sort of public; it is a more restrained sort of public, but it is about public policy. 
The third example is as follows: Two or three times a year, I give talks to various community groups about "Five things you think are true about Muslims, but which are not." Like, "They have more babies when they are in Europe," or "They don't like the US when they are in the US." As a matter of fact, they are more satisfied with life in the United States than the average American. So, five things, lots of quantitative data and graphs and stuff, which people, for better or for worse, tend to believe in. Less so with polls, nowadays. The last one I gave was in Montreal, to a group which styles itself as "The Davos of North America" - young leaders, lawyers, journalists, et cetera. A month before that, I spoke at the Humphrey School for International Affairs in Minnesota. The event was organized by a group of human rights lawyers in the state and an Islamic education resources group. And that was probably the most important thing I did, because the public there was not only the people in the audience, but the Islamic education resources group, which asked for my PowerPoints, because of the data. They said that they would be using the PowerPoints in their schools outreach. And so this is backing up their claims about how Muslims are fitting into the US in high schools and other venues around the state.

So, post-Trump, we may all be asking ourselves, "What can I do?" And I know what I am going to do-I am going to do a lot more of those. You know, once a month if possible, talking to schools, talking to broader publics if possible, in order to get the facts out about Muslims in the West-which is something I happen to know about. Now, are these anthropological publics? Well, the first one with Time Magazine was not particularly, so an historian could have done the thing I did for Time, a political scientist could have done it, but I happened to be the person they knew about, so they called me up. The second one, the public policy one, where I could talk at length, because I had a long-term engagement with young women and some young men getting married and having problems, would qualify. And it is mainly we as anthropologists who do this. The third one, well, yes and no: it tends to be we who think that we have got to do this, and to have a way of translating the Muslim experience in the US into statistics or into something else. You have particular kinds of concerns, but it is not the case that only anthropologists could do it. We have particular kinds of policy concerns which lead us to make these kinds of interventions. And these are not the only kinds of publics we could think of; there are others, I am sure. But I think we can all agree to find ways to engage with one or more of those publics, and that is what I am trying to do.

ILANA FELDMAN: I am going to turn now from our most recent electoral campaign to a campaign in the context of the American Anthropological Association: the effort, which I was involved in, to have the AAA adopt a boycott of Israeli academic institutions. This campaign resulted in a resolution which passed overwhelmingly at the business meeting last year (2015), but fell short of passing by thirty-nine votes in a vote of the AAA membership at large last spring. I am a scholar who works on Palestine, and it was my research and scholarship over the past twenty-five years (see, inter alia, Feldman 2008, 2015), and not my public outreach, that led me to a deep conviction that the boycott was the right thing for the AAA to do. I don't think you need to have twenty-five years of experience in Palestine to conclude that this is the right action to take. But I do think it is hard to 
have this kind of knowledge and not feel the imperative to act. And it is no surprise that an overwhelming majority of the scholars who are specialists on Palestine, or on the Middle East more generally, support the boycott. This support grows out of what we know from our research and experience. In noting the connection between my research, and the research endeavors of other Middle East scholars, and our commitment to the boycott, I gesture toward a larger point about the relation between our academic endeavors and our public speaking. These are not wholly separate activities - though they may be separated in either space, time, or formbut emerge together. And you know, scholars of the region feel a real responsibility to be responsive to the voices of the people and the places in which we work. And this is a general anthropological imperative in my view. I am going to return to this question about our relationship to the Palestinian public. But I want to take this moment to underscore my conviction that taking up the boycott would beand I hope will still be-an instance of the best in the anthropological tradition. It would put the power of our collective voice behind our commitment to justice. It would reject the status quo that denies academic, political, and human freedom to Palestinians.

Having made this statement about my politics, I want to reflect on the question of the public in relation to this. And I want to make two points. First, I want to consider the public to whom this boycott is intended to speak. It is intended to speak to a range of publics, beyond anthropology. It aims to speak to the Israeli public and government, to say that we refuse to engage in business as usual while the occupation and the violation of Palestinian rights continue. It aims to speak to the American public and government, to say that we reject support for these policies conducted in our name. It shows that the American public is not unanimous in support for the official US position. It speaks to the Palestinian public, to say that we hear them and respect their call for us to take action in solidarity with them. And I think that this is one of the great things about boycott as a tactic, precisely that it has multiple audiences and affects multiple publics to whom it speaks.

In thinking about boycott as an anthropological action that speaks to a range of audiences, to a range of publics beyond our disciplinary and professional borders, I also want to reflect on the anthropological public that was imagined, thought of, and instantiated in the boycott and in the debate around the boycott. In thinking about this, I put aside the people who think there is no problem with Israeli actions, and who think that the AAA should not stand with Palestinians at all. That is a separate conversation. I want to think about how the boycott was debated in a context in which everyone was claiming a concern for Palestinians. What kinds of publics were imagined in that concern? Some of the ways the debate unfolded, and the outcome itself, are reflective of what I think is a problem in the anthropological conception of the anthropological public. What I mean by that is that in that discussion, very frequently, Israeli anthropologists and Israeli academics at Israeli universities were thought of, and talked about as "our colleagues," as members of "our public," to whom we had a professional and collegial responsibility, whereas Palestinians (and again, I am talking about people who claimed a concern for the state of Palestinians) were talked about as a potential suffering nation, as people who might be victimized, and as people for whom we should have concern. But not as "our colleagues." This was not universally the case, but these were the terms in 
which many of the arguments against the boycott proceeded: that we had an obligation to our Israeli colleagues, part of "our" public, not to take any action that might harm them in any way. And when people made those kinds of arguments, about the potentially negative impact of the boycott on Israeli scholars, there was no discussion about Palestinians in the same terms. There was a discussion to the effect that "if we dialogue, things might be better," and there was the occasional expression of concern for Palestinians, but no consideration of Palestinians as having a voice that might be inside of our public.

This absence is just a single instance of what we all know is a long-standing problem in the anthropological public. There is a problem of who gets to be inside of our world. Whom do we not only have a relationship of care and concern for, but consider to be close to us, to be like us, and to be owed that kind of horizontal responsibility. Not just, whom do we have a relationship of care and concern for. I argue that we should and must approach the situation in Palestine as close to us, and approach Palestinians as our colleagues, as much as Israelis might be our colleagues. We should make our judgments about boycott based on (1) how it will reach and speak to the broader publics of whom I spoke before, and (2) how it will shape an anthropological public that includes our Palestinian colleagues.

ANGELIQUE HAUGERUD: I will focus my remarks on what might be termed a "public anthropology of the economy." But first, as we attempt to prepare for life under a Trump presidency, and to imagine its contours, it is already clear (in November 2016) that scholars will be challenged to grapple with what has been termed the era of "post-truth." Just before the election, the Oxford English dictionary selected "post-truth" as its 2016 international word of the year. Post-truth was chosen not in recognition of its novelty (since one can find similar cultural politics going back for centuries), but rather because of its ascendancy in contemporary politics in the United States, Britain, and elsewhere. So the "post-" in "post-truth," we are told, signals the irrelevance of facts-or knowingly repeating false talking points in an environment in which facts can be tarred as partisan, pessimistic, or even unpatriotic, or when the speaker of an inconvenient truth can be labeled as a "nasty woman" during a presidential debate, thereby diverting attention from the statement that elicited the epithet. "Nasty woman" then took off as an Internet meme, as Hillary Clinton supporters themselves reclaimed it as a rallying cry.

What were the substantive remarks by Clinton that triggered Trump's "such a nasty woman" interjection during a presidential debate? What Clinton was talking about at that moment in the debate was taxes. She said she would not cut Social Security benefits and would favor instead a modest increase in the Social Security payroll tax cap-noting that such a modification would affect her as well as the Republican candidate-assuming, she said, that he would not find a way to avoid paying that tax. A few days after the election, when Trump escaped the pool of journalists who normally accompany the president, and went out to dine at the elite 21 Club in New York City, he was caught on cell phone video assuring the wealthy patrons that he would reduce their taxes. "Taxes are not for everyone!" was a slogan of US satirical political activists I've studied (Haugerud 2013), and we may never know whether our billionaire president has paid any income taxes at all during 
the past two decades. ${ }^{4}$ During the presidential campaign, Trump's unprecedented nondisclosure of his tax returns received relatively little media attention, which instead often fixated on his tweets and his rhetoric about building walls, deporting Muslims, and ending the health insurance program known as Obamacare (the Affordable Care Act).

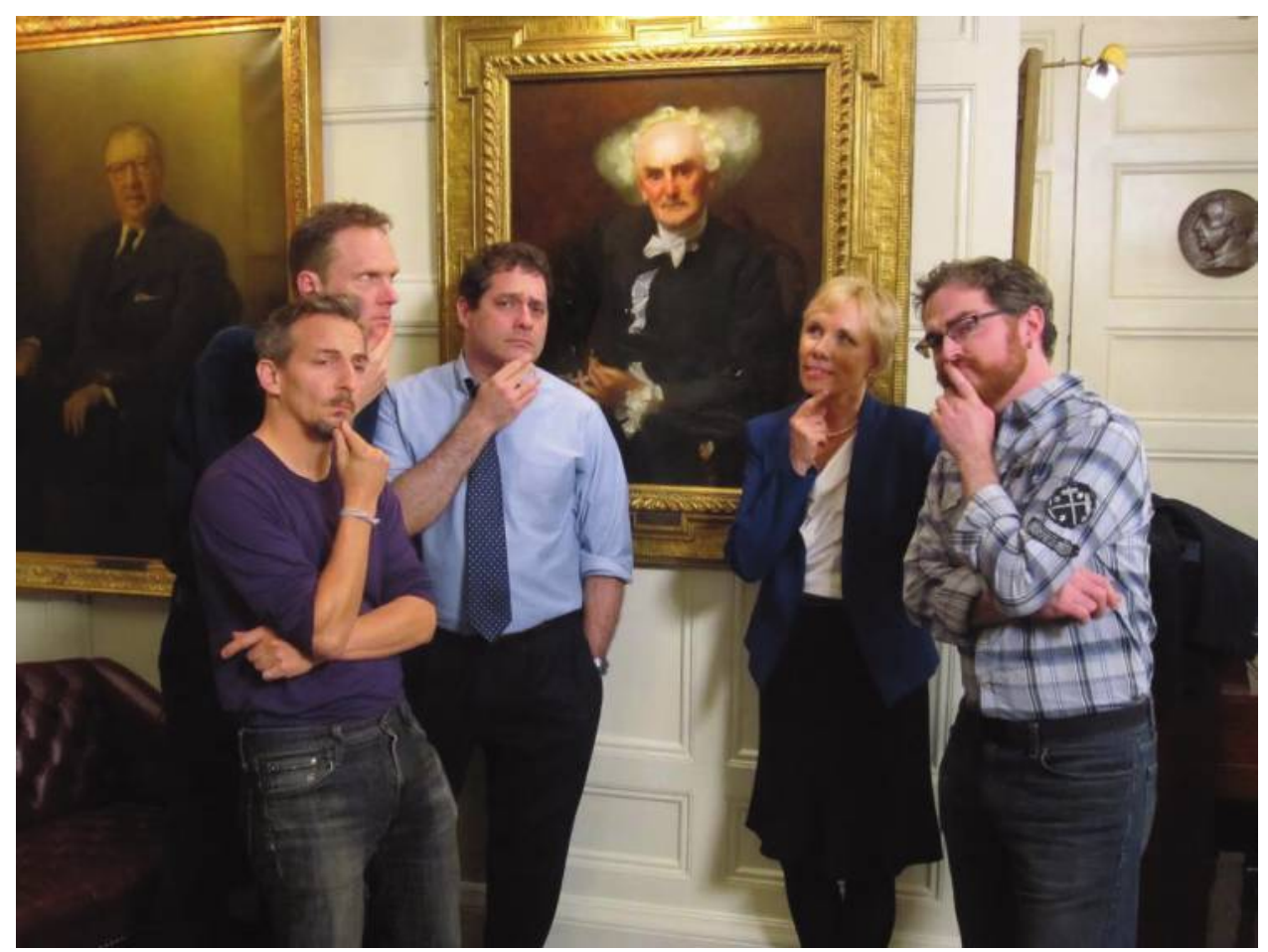

Photo Caption: Billionaires for Bush on tax day, New York City's central post office.

(Photo by Angelique Haugerud.)

Having witnessed a presidential election campaign in which, as the New York Times put it, "reality tops parody," just over half of US voters confronted an outcome that suggested tragedy. But great humorists such as Mark Twain remind us that "the secret source of humor is not joy but sorrow." "Bad news is good for satire," said cartoonist Garry Trudeau. Hence for years US satirical political activists who use irony and satire to challenge the status quo have found ample inspiration in the vast wealth divide between the ultrarich and the rest, the outsized role of money in politics, and issues such as tax codes that allow the very rich to guard their privileges (Haugerud 2013). Those privileges appear to face little danger under a Trump administration. Wall Street quickly rebounded after the elections, in apparent anticipation of expected rollbacks of financial regulatory reforms that were put in place after the 2008 financial meltdown. House Speaker Paul Ryan's economic agenda-though it is couched in ostensibly positive terms such as a "bold" progrowth agenda, opportunity, and "entitlement reform" - actually could privatize or

4. There was a partial leak of Trump's 2005 tax return in March 2017, after the time of writing. 
phase out Medicare, among other attacks on the social safety net, which has been unraveling during the past several decades, in what political scientist Jacob Hacker (2006) characterizes as a stealth crusade. In the United States, austerity programs are seldom labeled as such in the public sphere.

There is space here for a public anthropology that rejects the pitfalls of what Robert Atkinson and Michael Lind describe as a watered-down version of Economics 101-or economic simplifications that pervade public discourse (Haugerud 2013). Indeed, economist Philip Mirowski wrote that the economic crisis of 2008 "didn't manage to kill even one spurious economic notion" (2013: 14). Is the presidential candidate who won the electoral college and lost the popular vote poised to embrace what Mirowski refers to as "zombie-economic ideas" that refuse to die, such as trickle-down economics? And how would the new president's populist supporters respond to a continuation of the status quo that the candidate railed against during the presidential campaign?

Finally, we were asked how we would define public anthropology. As I stated in a recent year-in-review article in American Anthropologist (Haugerud 2016), I take this term to encompass knowledge production by professional anthropologists that is intended to reach beyond disciplinary specialists, and usually beyond the academy, in ways that differ from engaged, applied anthropology or practicing anthropology. Public anthropology, I wrote, is not about watering down or "thinning" academic work, but rather it aims to translate complicated ideas into widely intelligible and engaging language. There are tricks of the trade one can learn for that genre of writing. Writing style, however, is by no means the only obstacle to wider public consumption of anthropology. Indeed, some wonder if the discipline's message about complexity and context may face even deeper challenges today than it did a decade or two ago. In reviewing last year's public anthropology across a variety of genres, I was heartened to see that even during this time of growing anti-intellectualism, corporatization of universities, political and economic polarization, and what has been termed "post-truth politics," these challenges seem to have energized rather than quieted public anthropology.

DAVID PRICE: It is really interesting to think about what public anthropology really is, and about where the boundaries for this really are. I do a lot of work that is on the edge of public anthropology, and some that solidly lands on it. So I will start by talking about some of the things I do that do land within public anthropology. A lot of that starts with writing for Counterpunch. I have written for Counterpunch magazine and Counterpunch online for over sixteen years. I appreciate the idea of Time Magazine calling you and requesting "five hundred words" or "seven hundred words" in a couple of hours, because I can't stress enough that if you want to get your voice inside of a larger conversation, writing short and writing for a public audience is a very important way to do that. I have written eighty or so pieces for Counterpunch. And I am always surprised at how often they echo back somewhere else. The ways that they echo back are not always obvious. Sometimes, however, they are: if Democracy Now! calls up and wants to do a little ten-minute segment on what has been written, then there is a very direct echo and the point made in the piece comes out somewhere else. But probably less obvious is when the New York 
Times gets around to writing about the topic, which they often don't. In that case, it is often two to three months later, and I will get "background" phone calls.

And I have learned to always say more or less the same thing. That is, to say: "I don't care if I get quoted in this story at all; let me fill you in with my view." And I have found that one of the most important ways that I have been able to affect narratives is to get out of the story entirely. To say: "I just want to be background on this." It is not that I am off the record; I am on the record, and you can use a quote if you like, but I don't care if I am quoted or not. And I noticed since I started doing that that the conversations go on for much longer. If you have done work with the media, you will realize that the way to get quoted is to say the same seven-word sentence again and again. And it will show up in the piece, and it will be accurate, because it is not an eight-word sentence that is out there. I find it much more effective, though, to say: "Keep me out of the story, put me into the story, I don't really care; let us talk about all of these issues." And it really changes the narrative. I have done that with people at the New York Times. There was a long New Yorker piece on Julian Assange (Khatchadourian 2010) that I spent about four hours speaking to people on, and that I wound up staying out of entirely, which is more than fine with me, in terms of all the issues going round with that. But there were parts of the narrative that got in there that I could tell showed up as the neutral voice of the reporter. Which makes me think of maybe ten years ago or so, when the Human Terrain System (HTS) was around. There was a piece in a national newspaper where basically three paragraphs of my writing showed up unattributed-what we would think of as plagiarism in the academic world. And I got mad when I saw them in there, but my friend Alexander Cockburn told me to calm down and asked: "Shouldn't it be your words in there rather than theirs?". But there is some truth in there, in that if what you are trying to do is to influence the narrative, the more you can get out of the way, the better it is.

I also think I do public anthropology in another area in that I do a lot of public speaking. I talk at a lot of university campuses, where they are concerned about all these new CIA centers that are showing up on campuses. And I attend as many of those events as I can. I get calls from all over the United States, from schools that in order to make budgets meet face pressure from their administrations to accept these centers. So I do everything I can to go talk at those events, to provide some history, to talk about the moral issues, to talk about the political issues, and to talk about the ethical issues. And to do a sort of public anthropology about intelligence communities.

But I also speak at a lot of local public groups. I live in Olympia, Washington, which is home, it is the area I grew up in. It is also the state's capital. I get asked at least once a year to go talk to this Kiwanis group, which is a very unusual Kiwanis group in that everyone in state government is in there. And I go in, and do not pull any punches about national matters, Snowden, or security issues. I will get multiple calls from local lawmakers, who want to come and talk with me. I will go and have lunch with them; they know my politics are not their politics, but they want to hear the different sort of views that they're not hearing elsewhere

I also do a lot of Freedom of Information Act work, and when I get files, which I get loads of every month, I like writing up short summaries of public figures. So, I got Edward Said's files soon after he died. And I contacted his family to write up a 
nice narrative, which I first wrote up for Counterpunch (Price 2006), and then there was a secondary thing in The Nation which I contributed to (Cockburn 2006). And I very regularly write these summaries up for Counterpunch. I did one a couple of months ago on Ruth First ${ }^{5}$ (Price 2015). Having gotten her file, and from her own writings, I was struck by how anthropological her work was. I am doing a project on Saul Landau's file, which is massive; it is one of the largest ones I have seen. And so I am writing these summaries up as a way of informing the public about the history of surveillance, and about the history of the stakes of activism. And of course we know that right now, with what is going on politically, this history is going to be very important. The history of McCarthyism, for example, is going to be important with with developments under the Trump administration, with threats to our academic freedom, and so on. I really see a lot of the work that I have done and continue to do in looking at history, and worrying about the politics of this history, of trying to link these past threats to the present, as very relevant. So the talk that I am planning to give to this Kiwanis group in a couple of weeks from now is a talk about the social fact of progress. The Durkheimian notion of a social fact. Talking about it, we are all overcome with it. It feels like history works in a way that "you get rid of fascism, and it doesn't come back." It feels as if history works in a way that the threats of McCarthyism were something that you dealt with in the past, and they do not come back. But of course we live in a world in which we have to continuously fight these battles.

RICHARD ASHBY WILSON: I am going to start with some criticisms of the discipline of sociocultural anthropology. But first, a caveat: anthropologists can't control the world, and there are lots of reasons why our publics may not heed anthropologists as we rightly think they ought to. Some of these reasons have to do with our "post-truth" political environment, with the twenty-four-hour news cycle and the fact that the media have the attention span of a gnat, and we can't control any of those things. However, there are a few things that anthropologists can control, and if we addressed them head-on our work might become more publicly accessible and relevant.

There are three issues that we might consider, namely the degree to which anthropology is jargon, preachy, and overly focused on minutiae. First of all, few would dispute that sociocultural anthropology is entranced by theoretical jargon to an extent that excludes participation by a wider audience. Reading an anthropological article often requires the reader to have read and comprehended the complete, unadulterated, and unabridged works of Marx, Weber, Freud, Mead, Schmitt, Agamben, Foucault, and a host of other writers. Second, anthropological writing is often preachy and adopts a sanctimonious tone that alienates many nonanthropological readers. Authors implicitly demand that the reader share the political

5. Ruth First (1925-82) was a South African antiapartheid activist and academic and involved in the South African Communist Party (SACP) and the African National Congress (ANC). Forced to leave South Africa for exile in 1964, she was killed by a parcel bomb sent to her office in Maputo, Mozambique, by the apartheid regime's security branch assassins in 1982. 
and cultural assumptions of the writer before proceeding with the argument. Anthropological writing doesn't conventionally acknowledge alternative views or the degree to which the reader posesses an independent viewpoint that may require persuasion. The assumption is that all readers share the same cultural and political premises as the author and that the anthropological attitude is "it's either my way or the highway." This is commonly known as dogmatism, and anthropological writing could afford to strive more for open-mindedness. Finally, anthropological writing is overly focused on minutiae. We all agree that complexity is the hallmark of a rich and detailed ethnographic account, but often our accounts take the reader deep into the weeds of picayune and frankly irrelevant cultural practices that detract from the wider picture. Some time ago, I wrote a book review of an economic anthropology of peasant production in Latin America in which the author really did count the number of shovels and hoes in the garden sheds of peasants in his community.

And then there is the opposite problem, when the anthropologist, striving to be consequential in the field and garner the respect and admiration of his or her peers, makes grandiose claims but provides only a slim evidentiary base for them. We therefore have a situation where either there is an abundance of minutiae and there are no wider claims, or there are grandiose claims and there is very little evidence. Therefore my first recommendation in creating a more public and engaged anthropology is to start with a careful and honest examination of the place of evidence in our ethnographic accounts, with the aim of mooring theoretical claims more rigorously to evidence. Thus ends my critical foray into the inhibiting limitations of contemporary anthropological writing.

There are also many positive attributes of contemporary sociocultural anthropology worth applauding. Anthropology has produced very profound insights into the past and contemporary human condition. And the latest wave of nativism and neotribalism - and I am thinking here of Brexit, the election of Donald Trump, the rule of Victor Orban, and widespread attacks on immigrants in the slums of urban South Africa-does make sense for reasons that anthropologists have already identified. First of all: white identity is a thing. Few disciplines articulate the view as fully as anthropology that whiteness is just as much part of the landscape of ethnicity as minority ethnicities. Anthropologists such as Thomas Hylland Eriksen and others have been articulating this point regularly for the past twenty years. Anthropologists don't just talk about "the other," we also interrogate the "normal," the supposedly invisible default category of majority identity. And here I would refer to the work of Sherene Razack (2004) on Canadian soldiers and the work of Douglas Holmes (2000) on far-right movements in Europe. Anthropologists drew attention to this phenomenon as much as and possibly more than any other discipline.

Secondly, economic neoliberalism has had a deleterious impact on ordinary people's lives and livelihoods around the globe since the late 1970s. Anthropologists have documented the negative effects of neoliberal policies worldwide, including the hollowing out of the middle class and the end of manufacturing just as governments withdraw the social safety net. On the one hand, anthropologists are writing in ways that exclude us from public discussions, but, on the other hand, we are providing profound and important ethnographic insights that we are simply not entering into those public discussions. So what to do? I don't recommend stopping writing articles for academic journals or abandoning our scholarly conventions of 
excellence, and so on. I advocate continued scholarship with the sustained insight, rigor, and intense focus on detail that characterize much modern anthropology. But we could start writing more clearly, being more careful and consistent with our evidence and our claims, and adding a public version of our findings. I applaud David Price for talking about his public engagements. Writing op-eds or blogs is more necessary than ever, and some of you are already doing that. Anthropologists need to develop two authorial voices by adding a media voice to our anthropological voice. This means adopting a slightly different (and more humble!) persona, and it is going to take some time and some work, but it can be done. This will require speaking in a way that is direct, clear, convincing, and with a clear point without the usual anthropological humming and hahing and ritual genuflecting to Foucault and Agamben.

This year I have written a book about criminal incitement in international criminal courts (Wilson forthcoming) and I have been working on hate speech in other places such as Rwanda and the former Yugoslavia (Wilson 2015). Given my topic, I felt compelled to write about the rise of Donald Trump, and I wrote two op-eds this year. One was published in the Washington Post (Allen and Wilson 2016). My co-author and I asked the question: What does mass deportation of eleven million people actually entail? We sought to show the degree of violence involved in such mass deportations. We examined what happened in Bosnia, in the Trail of Tears, and other historical incidences in the United States and elsewhere when a minority group is persecuted and deported on grounds of ethnicity, race, religion, and so on. I'll freely admit one of my motivations was that I wanted to inform the US population in the hope that that they would turn away from this violent path.

Unexpectedly, in the process, I learned something important about the mood in the country in the run-up to the election. I would just like to end by reading out one of the over three hundred comments on my op-eds. The one I found most amusing claimed that I was part of the "Washington Post's liberal jihad against Trump"which I am happy to sign up to. Another posting stuck in my mind, and I went back and read it again after the Trump victory. I didn't quite know how to process it at the time, since it punctured my Northeastern liberal bubble. After Trump's election these words made much more sense:

He [Trump] is clearly a lout. He is a barbarian. If elected, he will be a national embarrassment. His election is unthinkable. Which is why I am going to vote for him. The US government has annoyed me for decades, and here is a legal opportunity for me to do it harm. Think of it as pinning the tail on the donkey.

My initial motivation was to educate the public and to counteract the "post-truth" claims during the presidential elections, aka an avalanche of lies. In the end, however, my public engagement taught me a thing or two about the values and emotional state of what Aristotle defined as the pathos, or emotional state, of the public. That's one of the unexpected benefits of a public anthropology for us anthropologists.

MAYANTHI FERNANDO: I have two comments that I want to put on the table. I want to come back to Irfan's initial point about doing an ethical anthropology, which we appear to have set aside, even though it seems to be the case that the 
relationship between a public anthropology and an ethical anthropology is actually a very tight one. And this relationship is something I have thought a lot about with regard to my own work on Islam in France (Fernando 2014). I think it is unsurprising that a number of us work on Islam and are thinking about the question of public anthropology. And something that has been difficult for me to think through is how to speak back to dominant discourses without reinscribing Muslims as a problem, or as the site of a problem to be solved. I think one has to be really careful that one doesn't reinscribe the preset questions when one responds to them in broader publics, that one doesn't reinforce the discursive terrain already at work. And I want to go back to Irfan's contribution and to a point that I think is really important, namely: How do we talk about Islam and about Muslims in a way that actually destabilizes the questions and disrupts the categories rather than simply reinscribes them? The example that came to mind was this question, "Are Muslims terrorists?" For the dominant discourse is that Muslims are terrorists. So, rather than saying, "No, no, they are not terrorists, and here's why," I think it is actually more interesting to do what Irfan did, which is to say: "Well, actually, Muslims are the ones being terrorized." Because it seems to me that this overturns and destabilizes the question, such that a new question might be asked: "Are Muslims being terrorized?" It is the same thing in France, with the original question being: "Are Muslims integrated?" And to say "Yes" or "No" actually reinscribes the paradigm of "integration" and of Muslims and terrorism. To say in your contribution, Irfan, that Muslims are actually the ones being terrorized in India strikes me as an exemplary move that we can all follow in doing a kind of ethical public anthropology.

The second point I want to raise is somewhat more provocative. I think of anthropology as an attempt not only to make the unfamiliar familiar, but also to make the familiar unfamiliar. As I was listening to this panel, I noticed that there is a way in which how we think about the "public" here keeps it a kind of liberal, Habermasian, discursive rational public. We are asking: "How do we speak to them, and how do we speak to liberals?" Yet to me, doing public anthropology is also about intervening in politics in different ways. And perhaps doing politics, rather than simply doing a public anthropology. It seems to me that what the Trump election revealed-and this is where anthropology's task of making the familiar unfamiliar comes in, why it works, and why we as anthropologists are important to politics and the public sphere-was the fact that politics is not rational, abstract, or secular. Or even perhaps democratic. Rather it's passional, libidinal, and even apocalyptic. And nonsecular, and possibly even antisecular. Rather than be horrified at that fact, I think it would be much more interesting, and perhaps more productive, for anthropologists to actually take that as the reality of politics. This is how politics works - and many of our interlocutors (or "informants") have taught us that already. In making this point that we might learn from our interlocutors, I am thinking of Michel-Rolph Trouillot's argument about anthropology as the "savage slot" (Trouillot 2003), in that we go elsewhere and come back with knowledge about the Other that we use to think about and better ourselves. I know that this is, of course, not all that anthropology does, and we tend to shy away from that moralistic aspect of anthropology now. But I think that there is actually a way in which we can marshal that so as to take seriously some of our interlocutors, who "do" politics in a very different way, in a passional way, in a libidinal way, in an eschatological or 
apocalyptic way, in a nonsecular way. And perhaps we can use that and draw on those very different ways in order to think differently about politics in the United States. It is simply not at all clear to me that the way forward-and this is intended as a provocation-is the reentrenchment of a liberal, deliberative, rational, and secular public sphere in a Habermasian mold. I think that there is something else going on in this moment, and I think that something else is actually productive to think with. And I believe that we as anthropologists may be well equipped to do just that, to think with that, and to do politics in the United States and Europe in a way that actually marshals that non-liberal, non-secular mode of thought and action rather than tries to deny it.

\section{References}

Ahmad, Irfan. 2009. Islamism and democracy in India: The transformation of the Jama'at-eIslami. Princeton, NJ: Princeton University Press.

—. 2011. "The (in)visible in Indian terrorism.” Al-Jazeera (English), September 16. http://www.aljazeera.com/indepth/opinion/2011/09/2011912104910716820.html.

Allen, Danielle, and Richard Ashby Wilson. 2016. “Deportation isn't just impractical. It’s very, very dangerous." Washington Post, September 23. https://www.washingtonpost.com/ opinions/mass-deportation-isnt-just-impractical-its-very-very-dangerous/2016/09/23/ c6d3b4ee-7b77-11e6-ac8e-cf8e0dd91dc7_story.html?utm_term=.c1168d7a2cc6.

Bangstad, Sindre. 2014. Anders Breivik and the rise of Islamophobia. London: Zed Books.

- Forthcoming. Anthropology of our times: An edited anthology in public anthropology. New York: Palgrave Macmillan.

Bowen, John R. 2015. “Three reasons France became a target for jihad.” Time Magazine Online, January 8. http://time.com/3660002/france-muslim-africa-organized-religion/.

-2016. On British Islam: Religion, law and everyday practice in Sharia councils. Princeton, NJ: Princeton University Press.

Cockburn, Alexander. 2006. “The FBI and Edward Said.” The Nation, January 12. https:// www.thenation.com/article/fbi-and-edward-said/.

Fassin, Didier. 2013. "Why ethnography matters: On anthropology and its publics." Cultural Anthropology 28 (4): 621-46.

Feldman, Ilana. 2008. Governing Gaza: Bureacracy, authority, and the work of rule (1917-67). Durham, NC: Duke University Press.

- 2015. Police encounters: Security and surveillance in Gaza under Egyptian rule. Stanford: Stanford University Press.

Fernando, Mayanthi. 2014. The Republic unsettled: Muslim French and the contradictions of secularism. Durham, NC: Duke University Press.

Hacker, Jacob. 2006. The great risk shift: The new economic insecurity and the decline of the American Dream. New York: Oxford University Press. 
Haugerud, Angelique. 2013. No billionaire left behind: Satirical activism in America. Stanford: Stanford University Press.

—. 2016. "Public anthropology in 2015: Charlie Hebdo, Black Lives Matter, migrants, and More." American Anthropologist 118 (3): 585-601.

Holmes, Douglas R. 2000. Integral Europe: Fast capitalism, multiculturalism, neofascism. Princeton, NJ: Princeton University Press.

Khatchadourian, Raffi. 2010. "No secrets: Julian Assange’s mission for total transparency." The New Yorker, June 7. http://www.newyorker.com/magazine/2010/06/07/no-secrets.

Mirowski, Philip. 2013. Never let a serious crisis go to waste: How neoliberalism survived the financial meltdown. London: Verso.

Price, David H. 2006. "How the FBI spied on Edward Said." Counterpunch, January 13. http://www.counterpunch.org/2006/01/13/how-the-fbi-spied-on-edward-said/.

_ 2015. "Agents of apartheid: Ruth First and the FBI's historical role of enforcing inequality." Counterpunch 22 (9): 10-14.

Razack, Sherene H. 2004. Dark threats and white knights: The Somalia affair, peacekeeping, and the new imperialism. Toronto: University of Toronto Press.

Trouillot, Michel-Rolph. 2003. Global transformations: Anthropology and the modern world. New York: Palgrave Macmillan.

Wilson, Richard Ashby. 2015. "Inciting genocide with words." Michigan Journal of International Law 36 (2): 278-321.

-_- Forthcoming, 2017. Incitement on trial: Prosecuting international speech crimes. Cambridge: Cambridge University Press.

\section{Publics pour l'anthropologie et anthropologie publique: Table ronde annuelle de l'American Anthropology Association (AAA)}

Résumé : À partir d'une transcription de la table ronde organisée par Sindre Bangstad sur le thème "publics pour l'anthropologie et anthropologie publique", le 18 novembre 2016 à la conférence annuelle de l'AAA qui s'est tenue à Minneapolis au Minnesota - transcription par la suite éditée, annotée et complétée par Sindre Bangstad -, ce forum explore les expériences d'anthropologues dont la contribution est significative en matière d' "anthropologie publique". Il s'interroge notamment sur les obstacles structuraux qui limitent l'engagement de publics plus larges avec l'anthropologie publique à notre époque, et les points sur lesquels les anthropologues peuvent travailler pour remédier à cette situation.

Sindre Bangstad KIFO, Institute for Church, Religion and Worldview Research PO Box 45 Vinderen NO-0319 Oslo Norway sindre.bangstad@kifo.no 
Irfan Ahmad

Institute for Religion, Politics \& Society Australian Catholic University

215 Spring Street

Melbourne, Victoria 3000

Australia

i.ahmad@acu.edu.au

Ilana Feldman

Anthropology Department

George Washington University

2110 G Street, NW

Washington D.C. 200052

USA

ifeldman@gwu.edu

John R. Bowen

Department of Anthropology

Washington University in St. Louis

Campus Box 1114

One Brooking Drive

St. Louis, Missouri 63130-4899

USA

jbowen@wustl.edu

Angelique Haugerud

Department of Anthropology

Rutgers University

Ruth Adams Building $3^{\text {rd }}$ Floor

131 George Street

New Brunswick

New Jersey 08901-1414

USA

haugerud@rci.rutgers.edu

David H. Price

Anthropology

St. Martin's University

5300 Pacific Avenue

Lacey, Washington 98503

USA

dprice@st.martin.edu

Richard Ashby Wilson

Department of Anthropology

University of Connecticut 354 Mansfield Road

Storrs, Connecticut 06269

USA

richard.wilson@uconn.edu 
Mayanthi L. Fernando Anthropology Department University of California Santa Cruz 1156 High Street Santa Cruz, California 95064 USA Mfernan3@ucsc.edu 